\title{
1. The management of natural resources: an overview and research agenda*
}

\section{Gerard George, Simon J.D. Schillebeeckx and Teng Lit Liak}

Natural resources underpin the foundation of human activity. Individuals and organizations consume vast amounts of natural resources as a matter of routine without much cognizance of their continued availability in the future or the true cost of a depleting natural resource. Over the past decades of industrial activity, organizations, communities and nations have acted to protect their interests by investing in and securing their supplies of natural resources that support economic growth. An industrial complex, now variously termed as 'extractive industries', supplies crucial non-renewable natural resources such as oil and coal for energy or iron and aluminium for construction. Our societal reliance on the consumption of natural resources grows unabated such that the discussion of sustainability of natural resources has taken primacy in policy and executive concerns. However, scholarly research on understanding the management and the organization of natural resources remains limited, especially regarding its industrial ecosystem of use and trade and its implications for individual behaviour, organizational performance and quality of life.

Since the 2008 food crisis, food supply uncertainty has driven up competition for land between countries, food and energy crops growers and speculative financial investors (Smaller and Mann, 2009), which in turn has affected prices, local availability and the livelihoods of many. The relative scarcity of potable water, in combination with the dramatic effect of local shortages on agriculture and livelihood, has put water risks and opportunities among the top sustainability issues (Ernst \& Young, 2012; McNally, 2015; PwC, 2011). According to the United Nations (UN) (2012), 783 million people do not have proper access to drinking water, and, in sub-Saharan Africa, water is unavailable to over 40 per cent of the population. More than 850 million people are undernourished and at risk of starvation, and over 1.1 billion do not have access to energy, which necessitates innovative business models for 
off-grid rural areas (Schillebeeckx et al., 2012). In a study of Indian slum settlements, Parikh et al. (2015) found that the provision of water services increased education by 62 per cent and income by 36 per cent by freeing up the time women spent on fetching drinking water, pointing to the link between basic resources availability, social development and the labour market. Access to water and energy has the effect of shifting individual aspirations upwards to health, education and land ownership (Parikh et al., 2012). However, the industrialization and growth in world economies is yet to provide equal access to basic natural resources such as food and water for sustenance. Food, water and energy remain basic natural resources that face scarcity and disproportionate access inequality.

With energy minerals, recent reductions in the oil price are causing havoc to investments in the natural gas and shale gas markets. A Carbon Tracker study on stranded assets convinced the largest sovereign wealth fund in the world to set up an expert panel that initiated a significant divestiture of coal assets and eventually an outright ban on new coal investments (Carrington, 2015). In addition, various non-energy minerals and metals are facing increasing constraints. Lithium price increases driven by the electric vehicle industry's demand for lithium-ion batteries risk pricing other lithium-using industries (for example, electronics, ceramics, glass, lubricating greases, nuclear technology and various medicines) out of the market and in search of substitutes.

Ernst \& Young's (2013: 21) report on growing trends in sustainability pointed to the 'increased risk and proximity of natural resource shortages', meaning that assessing the availability and reliability of strategic business materials and developing risk management plans to address supply disruption contingencies become strategic imperatives. These recent evolutions in the natural resource debate and the presence of scarcity-related issues across a wide variety of renewable and non-renewable resources, local and global challenges, small, medium and large enterprises and resource-rich and resource-constrained countries evidence a clear need for management scholars to engage and support this debate with systematic evidence.

$A M J$ editorials on climate change as well as risk and resilience highlight the growing importance of organizational action to address large-scale, seemingly intractable, societal grand challenges (Howard-Grenville et al., 2014; van der Vegt et al., 2015). In this editorial, we review past work in $A M J$, and, not unexpectedly, find that, while we have made expansive use of the term 'resources', specifically when it pertains to employee resources and human assets, the focus on natural resources has lagged significantly behind. We provide a simplified overview of work in $A M J$ over the past 50 years on the broader use of resources, and focus instead on themes identified in natural resources as a context. 
Our intention is to inspire management scholars to take up the 'grand challenge' to provide strategic and managerial insights in conversations and debates that have so far been held by policymakers, economists, natural scientists and engineers. As organizations' objectives can diverge from those of governments, citizens and stakeholders, the interplay between corporate decisions, institutional and regulatory actions, societal pressures and important externalities of extractive processes provides an exciting context for theoretical and empirical research. We provide examples of how natural resource scarcity is challenging businesses, governments and industries at large to innovative technologies and business models, compete in natural resource markets and collaborate across industrial, national and cultural boundaries.

\section{'RESOURCES' IN $A M J$}

As the flagship empirical journal of the Academy of Management, $A M J$ has a strong impact on what is being studied in the field of management at both macro and micro level. Therefore, the journal not only inspires research across a wide range of other journals but also reflects the highlevel and theoretical conversations that are being held in those journals (Joshi et al., 2015). EBSCO hosts 3,456 articles published in $A M J$ between 1963 and $2015 .{ }^{1}$ Within this population, we find 319 that have 'resource*' either in the title, abstract, author-supplied keywords, or subject terms. Those 319 articles were analysed to reveal broader patterns of discussions on resources. Of all selected articles, only one mentioned 'natural resources' as a keyword. For comparison, 'information resources' were mentioned 57 times, 'resource allocation' 58 times, 'resource management' 53 times, 'resource-based theory' 21 times, and 'resource-dependence theory' thrice. Also, studies focusing on human resources - with keywords like personnel management, human capital, employee attitudes, selection, recruitment, or training, job satisfaction, or performance labour turnover or productivity - occurred more than 200 times.

Prior attempts to categorize resources have distinguished between human, financial, physical, technological, organizational and reputational resources (Grant, 1999). Others have provided a typology for intangible resources differentiating between human, organizational, technological and relational capital (Fernández et al., 2000). What is common across studies is that most resource typologies have been inspired by resourcebased theory and have focused on resources that exist within organizational boundaries, with some extensions to relational resources (Dyer and Singh, 1998). Within institutional theory, Rojas (2010) differentiated 
between symbolic, coercive and normative resources. Table 1.1 provides an overview of a selection of exemplary articles that capture a specific way in which resources have been conceptualized in $A M J$.

The overview suggests that $A M J$ articles that mention the term 'resources' fall under three broad categories: (1) people as resources, including the human resource, human capital and social capital perspectives; (2) organizational assets as resources that frame resources as a state (slack or distribution), type (specific capabilities or assets) and action (bundling or deploying) and (3) interorganizational and societal resources that address jointly produced or controlled resources that lie outside the focal firm or within or across firms and communities.

What becomes clear is a striking lack of attention to natural resource issues. Bode et al. (2011) focused on supply chain disruption in manufacturing, but their survey did not investigate whether natural resource availability caused disruptions. Powell and Baker (2014) examined how resource-constrained founders respond differently to adversity, and, while acknowledging the relevance of exogenous material constraints, focused on differences in founder identity. Boone and Özcan (2014) investigated the emergence of cooperatives in the US bio-ethanol industry. In general, when natural resources are mentioned, they are a constitutive part of the context in which another phenomenon is being studied.

\section{NATURAL RESOURCES IN $A M J$}

Given the absence of natural resource-related articles in the original sample, we looked for articles using various 'natural resource-related' keywords. ${ }^{2}$ This resulted in 264 articles. Because we needed to look broadly for keywords that refer to natural resources in our second sample, a significant number of the found articles were irrelevant, as they used the keywords in a different context (for example, 'materials' from the sociological literature, the 'nature' of research/business/the problem, data as 'inputs' for use/inputoutput model of behaviour/labour inputs). As such, of the 264 articles originally selected, 175 were dismissed because they were included based on a different meaning of one of the search terms, leaving 89 articles that potentially provided insight into how natural resources have featured in $A M J$.

These 89 articles can be split into two groups. The majority mentioned a specific natural resource as a context in which unrelated questions were studied. Hence, the natural resource in question was not a focal part of the study, and is incidental to the management theory being tested. The lion's share of these studies focused on individual roles and effects, which is consistent with our previous findings regarding the attention to human 


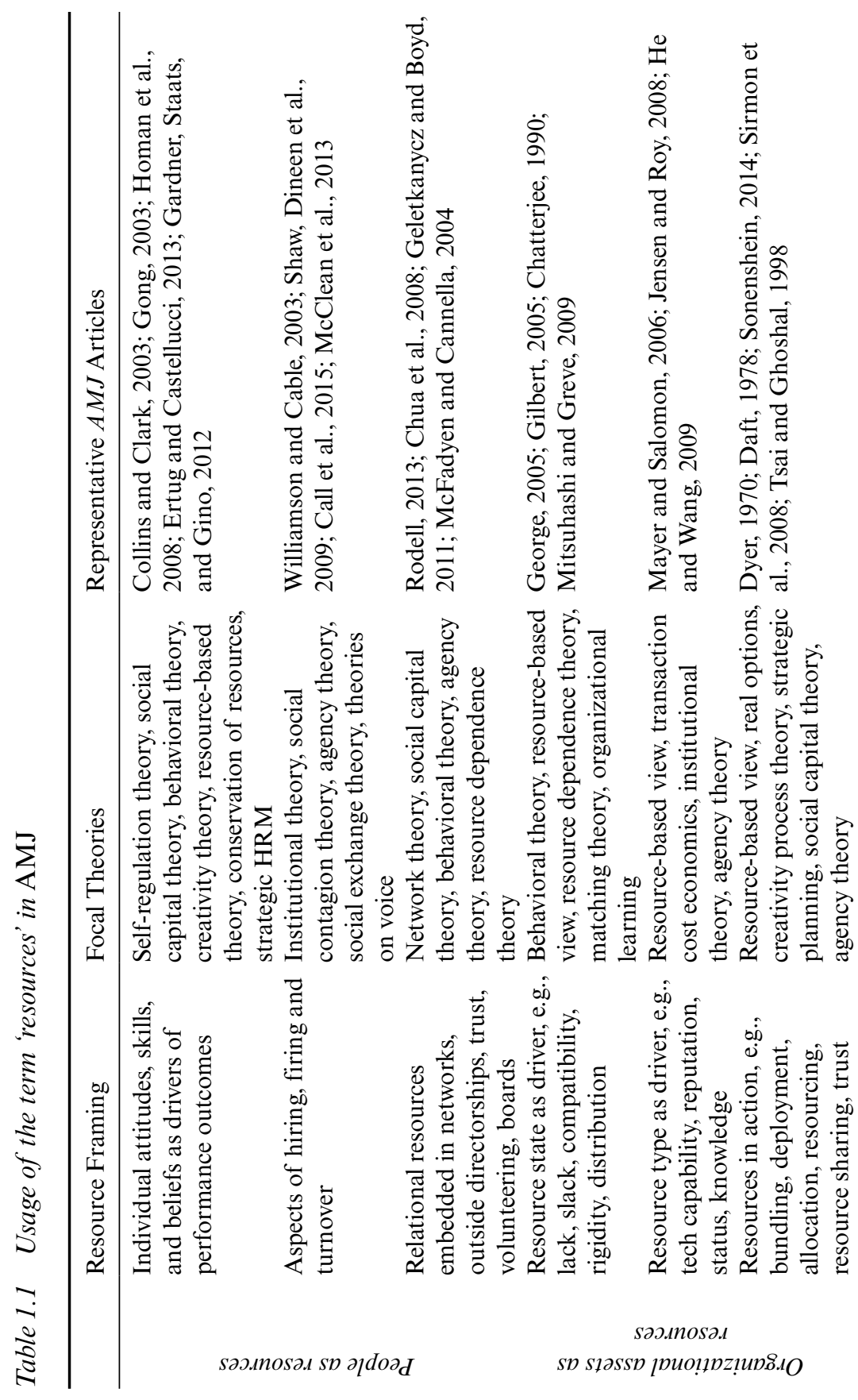




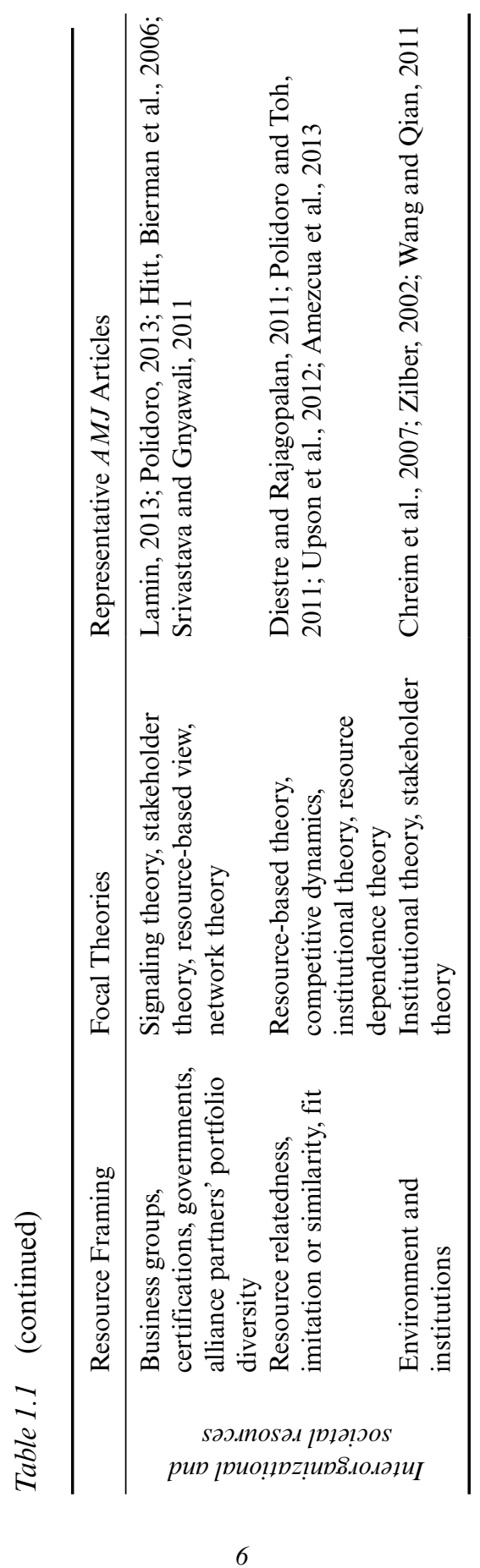


resources. Given the similarity with Table 1.1, we provide representative example studies in the Individual roles and effects row of Table 1.2. The following two rows focus on Individual attitudes toward the environment and on Organizational attitudes and performance outcomes.

Besides the areas of research exemplified in Tables 1.1 and 1.2, a few other subdomains emerged from the literature review, with significant attention to regulatory and institutional perspectives. Studying the origins of regulation with regards to genetically modified organisms, Hiatt and Sangchan (2013) posited that regulators are influenced by assessments of powerful stakeholders and peer agencies concerning the issues at hand. More attention was paid to organizations' responses to regulations. In the nuclear energy sector, Marcus (1988) found that organizations with poor safety records responded in a rule-based manner while those with stronger safety records responded more autonomously, thus hardly improving general safety. Studying the organic food industry, Lee (2009) investigated the relationship between local and federated standards-based certification organizations and changes in US state laws, and concluded that local structures enhance legal innovation and elaboration but reduce variation, while the opposite holds for federated structures. Madsen (2009), perhaps counter-intuitively, found that more stringent regulation need not result in less corporate investment in the regulated region. Additionally, environmental policy, in combination with management support, positively influences employee eco-initiatives (Ramus and Steger, 2000). Some regulatory externalities were also presented: Utilities heavily reliant on nuclear energy provide leadership, and this leadership negatively relates to public safety (Osborn and Jackson, 1988). Furthermore, pollution regulation erects barriers to entry (Dean and Brown, 1995).

At the institutional level, Hoffman (1999) found that organizational fields can form around issues such as environmental impact in the chemical industry. Maguire and Hardy (2009) studied the eradication of DDT (chemical) usage to reveal institutionalized practices abandoned through defensive institutional work, and that field-configuring events, via the mechanisms of new discourses, can change institutional fields (Hardy and Maguire, 2010). Building on that work, Schüssler et al. (2014) looked at UN climate conferences and showed that variations in field-configuring events' structures, processes and outcomes can explain the failure to bring about institutional change.

The takeaways from this synoptic overview of (natural) resources are threefold. First, theoretical diversity has allowed 'resources' to be conceptualized and operationalized in distinct ways, but this multiplicity has created an all-encompassing category in which everything is and can be a resource. Second, despite this broad categorization, management scholars 


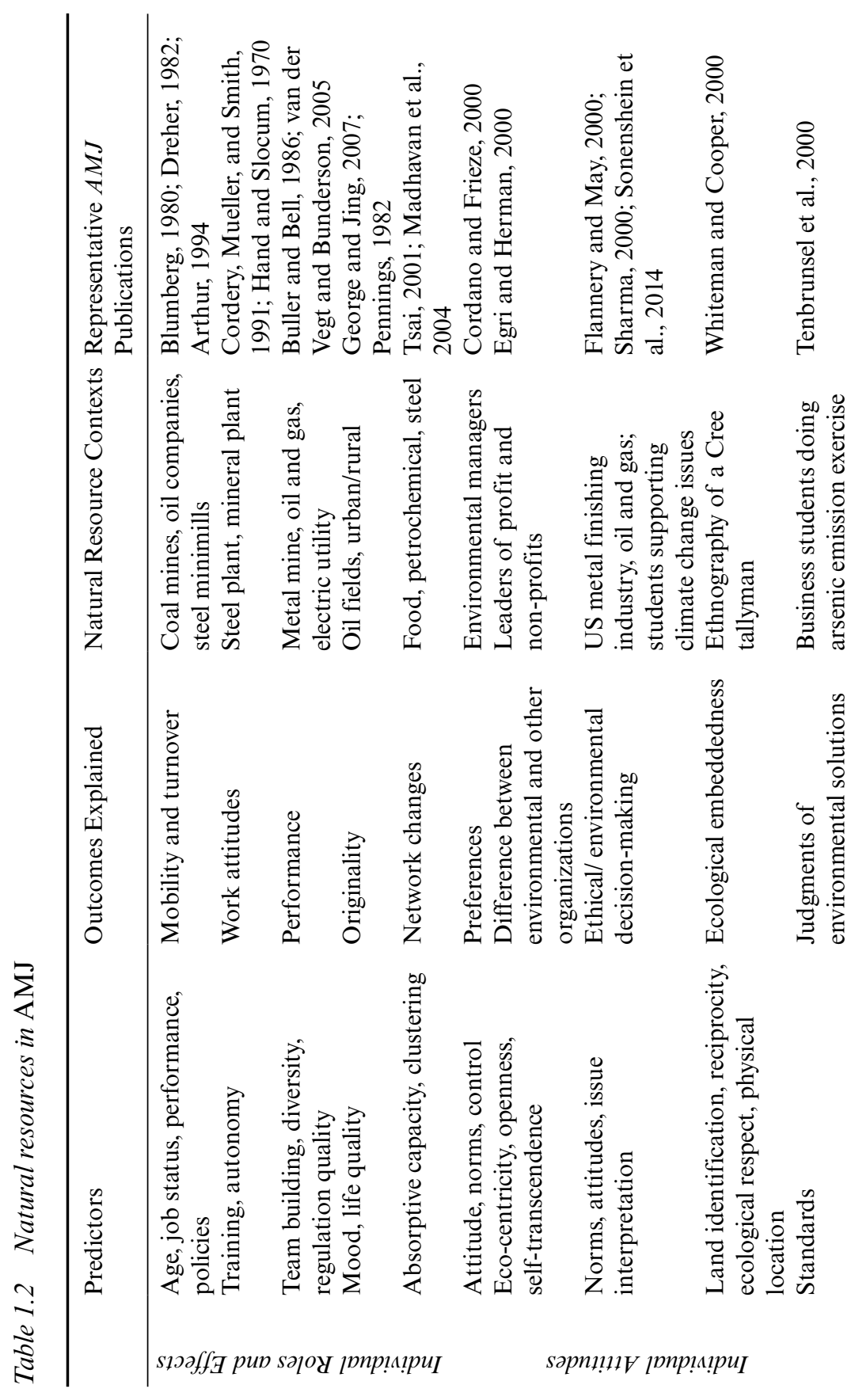



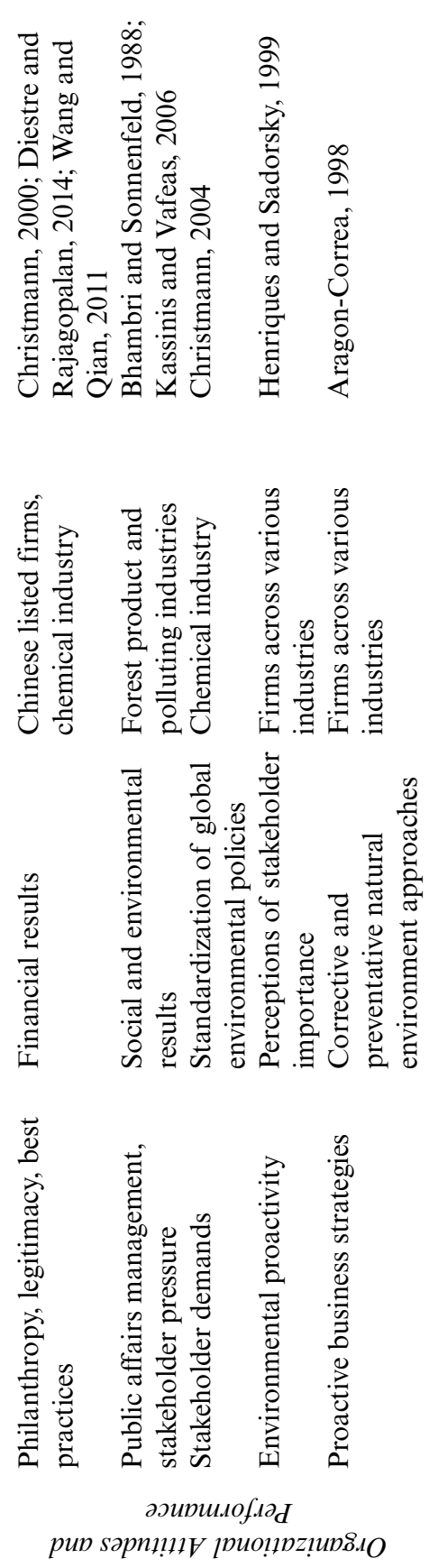
have paid only scant attention to physical and natural resources and their idiosyncratic characteristics; this in direct opposition to human, relational and knowledge resources. Third, in the past two decades, attention to corporate social/environmental responsibility and to regulatory and institutional aspects of the natural environment has risen, but this increasing attention has not been accompanied by a stronger focus on natural resource inputs or throughputs in production and social processes.

\section{WHAT MAKES RESOURCES SCARCE?}

Resource scarcity has been on the agenda of economists, politicians and environmentalists for centuries. Over the years, the meaning of 'scarcity' has been subject to considerable modification. In the eighteenth century, Thomas Robert Malthus (2005/1798) feared that agricultural land would be incapable of providing enough food for an ever-growing population, while, in the early nineteenth century, David Ricardo (2014) stated that scarcity was a function of different grades of ore quality. This implies a transition from biophysics to technology as the focal constraint on resource availability. Howard Hotelling (1931) conceived of an 'economics of exhaustible resources' and concluded that scarcity is transparent in resource prices, hence providing a market rationale for scarcity. The rapid growth of the post-war economy sparked doubts as to whether market prices were suitable mechanisms to avoid resource exhaustion. Tober (1974, in Brown and Field, 1978), for instance, submitted that prices of wild pigeons remained stable until their complete extinction in 1890 . Much later, social psychologists concluded that humans have a strong tendency to overconsume physical, spatial and temporal resources (Herlocker et al., 1997), with Easter Island as the prototypical example. The seminal The Limits to Growth foresaw economic collapse due to food and mineral shortages (Meadows et al., 1972), thus echoing Malthus, while the 30-year update brought more pessimism due to squandered opportunities and highlighted the impact of exploitation on natural ecosystems (Meadows et al., 2004).

The past two decades have chiefly focused on these ecosystem implications, with climate change and global warming becoming part of our daily vocabulary. The current discourses on planetary boundaries (Rockström et al., 2009), resource security (Buijs and Sievers, 2012; Defra, 2012), and the resource nexus (Workman et al., 2016) are the latest evolutions on the topic of scarcity. What these modern interpretations of scarcity show is that the geochemical or biophysical availability of natural resources is not the focal constraint on resources' availability. Given the plurality of scarcity drivers 
and the associated uncertainty, it becomes crucial for governments, organizations and individuals to respond to such causally ambiguous exogenous resource constraints.

Thus far, the management field has mainly used a singular frame to address scarcity - the resource-based view, which defines resources' rareness as imperfect market competition (Barney, 1991). Imperfect competition affects many natural resources as they are subject to, for example, regulation, risk of government appropriation, large capital requirements, immovable production factors, information asymmetry and increasing returns to scale. Also, prices are often set in private negotiations (many scarce minerals), or, in other cases, are heavily subsidized (water, agricultural land) and thus markets cannot function efficiently. Providing we are agnostic about the determinants of scarcity, our understanding of phenomena that are influenced by imperfect markets remains limited.

Many metals are used in relatively small quantities in various markets (Table 1.3), but their unique properties make substitution difficult, and so price volatility or shortages lead to severe supply chain disruptions. The rare earth market, for instance, dominated by Chinese production, has been associated with lawsuits in front of World Trade Organization (WTO) tribunals (Hook et al., 2012). When China reduced its export quota, prices surged by up to 850 per cent in the second half of 2010 (Humphries, 2013). More generally, various financial market specialists argue that we have reached a paradigm shift: the 100 years of ever-cheaper commodity resources are permanently over and increasing competition and rising prices for ever-scarcer resources will become the new norm (Grantham, 2012).

\section{MANAGERIAL IMPLICATIONS OF NATURAL RESOURCE SCARCITY}

As a field, we have worked under the assumption that the tangible (natural) objects being managed are much less important than the intangible aspects that characterize the nature of management itself. Considering recent events in natural resource markets, this assumption appears deeply flawed. Specifically, the World Economic Forum (2008) reported that supply chain disruptions, food security, energy security and systemic financial risks are the four most important emerging issues. The first three are intrinsically connected to natural resources, and they impose grand managerial challenges. In this section, we highlight several areas as having potential for scholarly dialog and empirical research. 


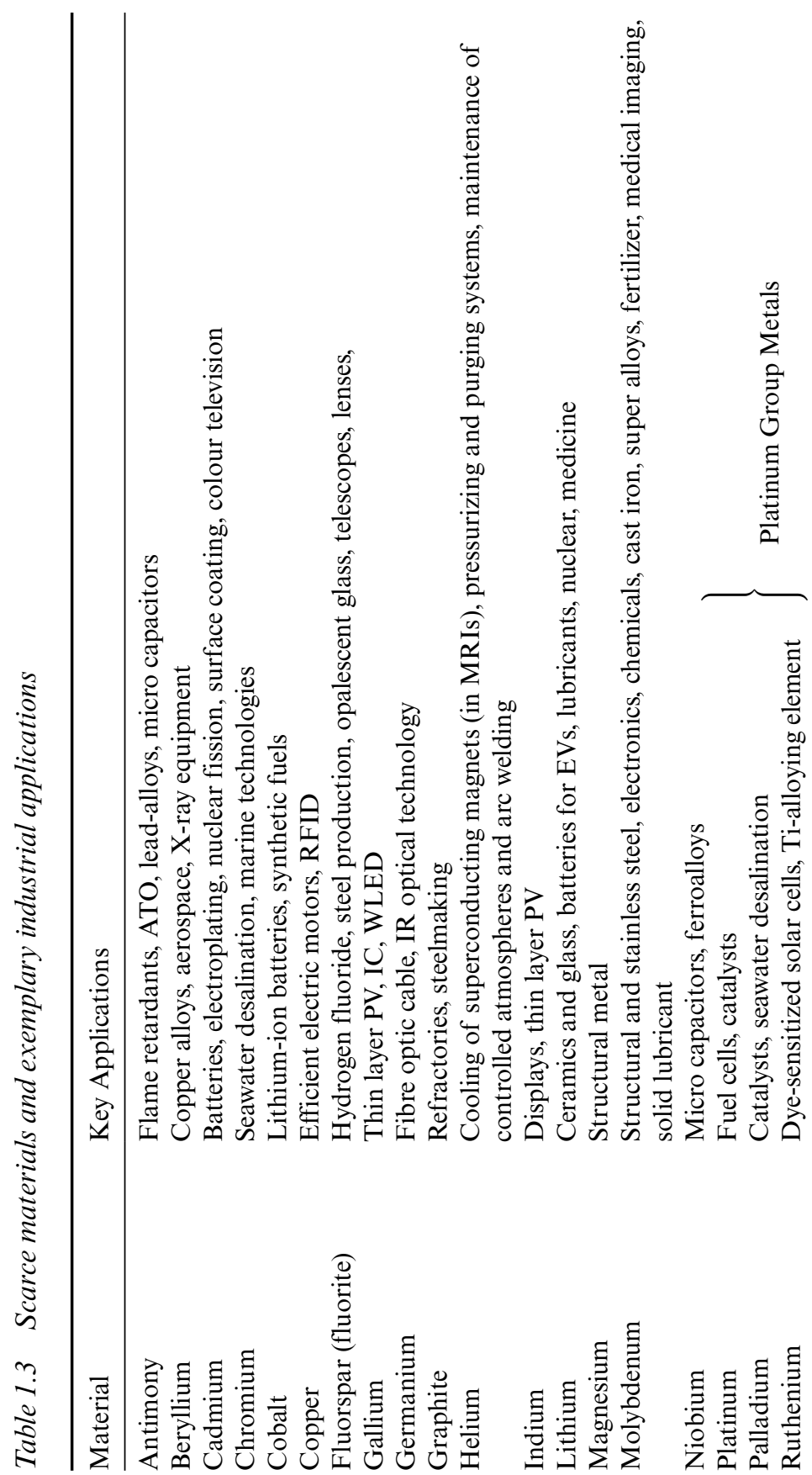



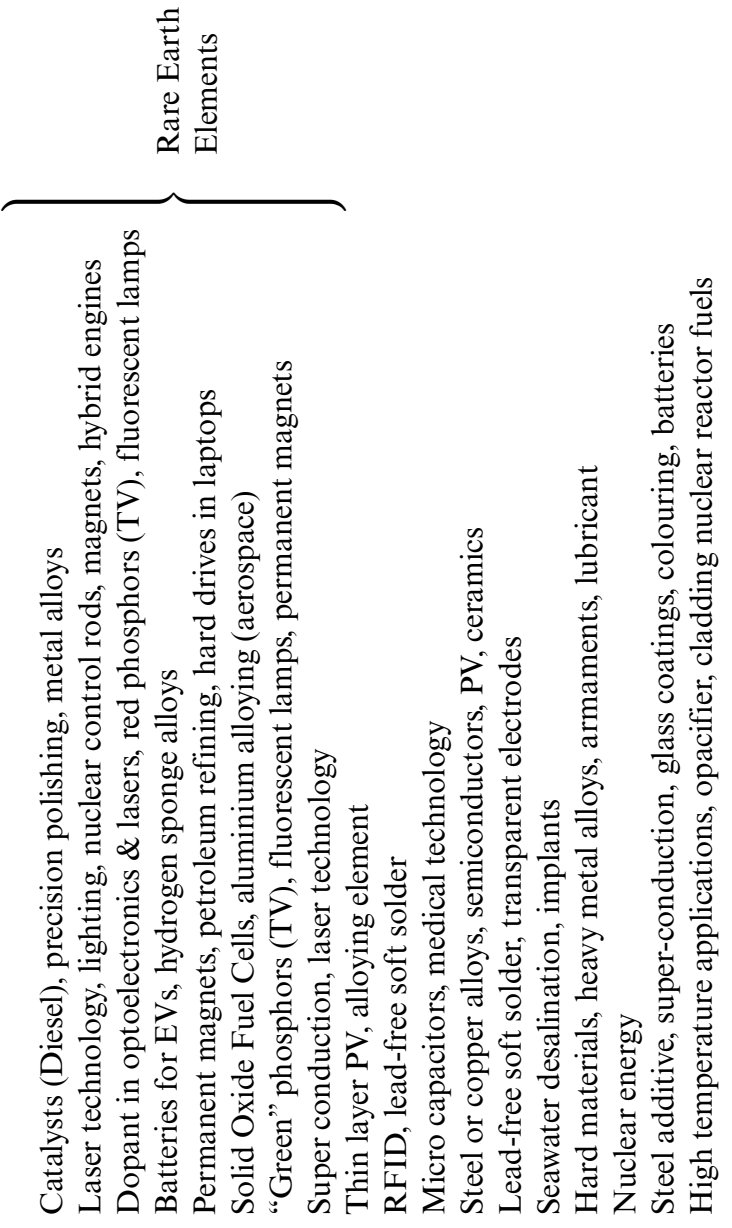

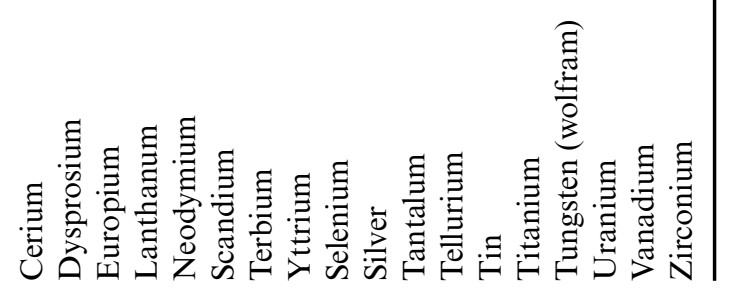




\section{Organizational Responses to Scarcity}

Natural resource scarcity potentially affects organizations in multiple ways. Schoolderman and Mathlener (2011: 5) found that global manufacturing executives increasingly worry about natural resource scarcity and that new business models and supply chain innovations 'will be fundamental to the ability to respond appropriately to the risks and opportunities posed by scarcity of minerals and metals'. Relatedly, an executive survey of UK manufacturers put raw material shortages as the most critical challenge for the companies' survival (EEF, 2012). Hence, not surprisingly, we witness multiple corporate actions to ensure stable natural resource supply.

Toyota invested in two collaborative projects, one with Indian Rare Earth in Orissa and another with Vinacomin (Vietnam) and Sojitz (Japan). A diverse group of German companies, such as BMW, Daimler, Bosch, BASF and Bayer, have formed an alliance to secure key raw materials in the face of mounting competition from emerging economies. Land acquisitions by big multinationals in Africa and Asia risk exacerbating malnourishment in local population, as these 'land grabs' often take place in countries where hunger is a societal problem (Rulli and D'Odorico, 2014). This is accompanied by increasing state-based foreign investment in foreign lands with a view to a lock in access to water for agriculture (Smaller and Mann, 2009).

Scarcity also inspires business model and design innovations such as longer-lasting products, modularization and remanufacturing, component reuse and designing services with less material (Allwood et al., 2011). General Electric is working with the US Department of Energy to find ways to make permanent magnets (fundamental to wind energy) using nanotechnology to reduce rare earths needs by 80 per cent (Ernst \& Young, 2011). Tesla set up a recycling scheme with metal-recycler Umicore to ensure a proper end-of-life treatment of Panasonic/Tesla batteries. By investing in this urban mining partnership, Tesla increases the supply of natural resources in the long run. In general, urban mining offers the promise of higher yields and lower externalities than many virgin mining operations, but it requires smart initial design for it to be economically viable. Ford took a different road and switched to lithium-ion batteries for its Fusion and C-Max models, thereby reducing the need for dysprosium, the most expensive rare earth metal. Unilever has taken up the challenge of frugal innovation, with an ambitious goal of doubling its revenues by 2020 while reducing its environmental impact by 50 per cent. Key in its achieving this will be to successfully reinvent soaps and detergents so that they use less water.

Entrepreneurial ventures can alleviate concerns of resource availability. 
Innovation Metals Corporation's business model increases market efficiency through the establishment of a rare earth exchange through which scarce metals can be traded as commodities, and through the development of a platform based on a centralized multi-purpose refinery. Following the formation of the Impact Investment Exchange Asia and Impact Partners, a direct investment platform, Shujog was created as a non-profit, the objective of which is to assess impact and quantify it so that organizations can measure and magnify it.

More generally, 'ecopreneurship' and social entrepreneurship are on the rise. Consider the story of PlanToys, a Thai company that reasoned back in 1981 that decommissioned rubber trees could be used to make toys rather than be burnt. Besides starting a successful business, their idea created an end-of-life market for these latex-producing trees, thereby supporting local farmers' livelihood. In another example, the Dutch Embassy in Bangkok is launching a social enterprise incubator for entrepreneurial students and young starters from the ASEAN region and the Netherlands. The first iteration of the project will start in January 2016 and aims to tackle local waste problems. UK-based start-up Provenance combines state-of-the-art blockchain technology Ethereum with an ambition to track the origins of materials securely and anonymously so that companies do not have to disclose their entire value chain. By tracking the origin of materials, Provenance intends to make working conditions and environmental externalities associated with natural resource extraction transparent.

In the management literature, the importance of the environment as a constraining factor on firm behaviour has been stressed in various organizational theories, such as institutional theory, resource dependence theory and population ecology. Firms generally seek munificent environments and attempt to enhance the munificence of their present environments, by increasing political, economic, technological, structural and social forms of capital. The last few years have exhibited a great variety of managerial practices and strategies to respond to scarcity induced environmental challenges. These emerging strategies warrant the extension of existing theories and perhaps the introduction of a new theory that explicitly addresses tangible (natural) resources.

\section{Institutional Responses: Government Intervention}

Policymakers are expressing growing concerns about the influence of resource availability on their country's growth and local companies' ability to compete in global markets. ${ }^{3}$ Governments' primary function in the market is to establish and enforce the rules of the game. The UK's Department for Environment, Food and Rural Affairs' waste policy (Defra, 
2011) and the European Waste Electrical and Electronic Equipment directive are examples of how governments have attempted to shape industrial practices by enforcing standards on recycling. The European Restriction on Hazardous Substances and the Registration, Evaluation, Authorization and Restriction of Chemical Substances are exemplars of how governments can steer industry behaviour by enforcing limits on the free use of materials that have a negative impact on human well-being. The US Rare Earths Supply-Chain Technology and Resources Transformation Act of 2010 is oriented towards re-establishing a competitive domestic industry for rare earth production, and thereby the US government is supporting a revival of an extinct industry. Such policy texts are essential parts of institutional discourses that justify intervention. How these discourses influence corporate discourses (and vice versa) on these issues offers an interesting avenue for future research.

When governments lack resources, they cannot make the rules nor create an incentive structure for companies to behave appropriately. In these situations, countries are taking action in the WTO to enforce free markets and competitive pricing. The WTO upheld a ruling that China's policy regarding raw materials exports violated international trade rules, which prompted the USA, Japan and the EU to officially challenge China's rare earth policy (Hook et al., 2012). Prices for select rare earth oxides are significantly cheaper within China than elsewhere, and the difference exceeds the export taxes imposed by the Chinese government. Such price differences are an example of how the Chinese government has used its market dominance. While there is a case to be made that lower local prices can be justified, as producing countries absorb negative mining externalities, those in need of resource access have generally downplayed the value of such arguments (Hayes-Labruto et al., 2013).

Besides making and enforcing rules, governments are establishing partnerships with resource-rich countries and are sharing technology and knowledge in exchange for access to scarce resources. Japan exchanged nuclear technology with Vietnam, the country with the fifth-largest rare earth deposits, and signed partnerships with Kazakhstan and India for the joint development of rare earth mines, making promises about cooperation on nuclear technology in return (Miyazaki, 2012). Germany built partnerships with former Soviet countries, such as Russia, Mongolia and Kazakhstan, to develop mines, and South Korea forged agreements with resource-rich nations, often through direct involvement of government entities (Ernst \& Young, 2011; Vateva, 2012). Such countertrade has not been studied extensively in the last decade. When governments take such direct action in the market, what are the effects on competition? On the one hand, government actions could level the playing field for resource-dependent 
companies, ensuring equal access to required inputs. On the other hand, they risk alienating innovators that are developing alternative products or services that do not require the same natural resource inputs. Thus, empirical evidence is needed to show whether government involvement merely postpones the inevitable decline of specific sectors or if it can indeed help overcome supply uncertainty and stabilize markets.

In addition to technology exchange, governments set up platforms for collaboration within and across their countries' boundaries. The German government established the Centre for Resource Efficiency in cooperation with VDI, the German association of engineers, and set up a Resource Efficiency Network (Federal Ministry of Economics and Technology, 2010). The Interreg (European Territorial Cooperation) supported cradleto-cradle network brings together governmental agencies and industry specialists from the Netherlands, Flanders (Belgium), Slovenia, Bulgaria and Italy. The project aims to spread best practices around cradle-to-cradle design (McDonough and Braungart, 2002) across its members and supports a variety of research implementation projects.

Finally, governments aim to decrease uncertainty in their regional markets by facilitating the development of new (or old) mines. During the rare earth crisis, the US government actively supported the reopening of the Mountain Pass mine with special environmental permits. Molycorp invested nearly 1 billion USD in rejuvenating equipment and making the mining process more environmentally friendly. This was hailed as being a heroic move for an American corporation, vital for national security (Martin, 2011). Yet, only a few years later, the company filed for Chapter 11 bankruptcy, costing investors all over the country a massive financial hangover while the national security discourse had completely disappeared (Heffernan, 2015). The German government's Raw Materials Strategy details financial support available to companies through a variety of mechanisms (Federal Ministry of Economics and Technology, 2010). The Institute for Geosciences and Natural Resources surveys potentially rich raw material zones for the benefit of German businesses and supports exploration efforts. Japan is looking into sub-ocean mining, increasing recycling capacities and stockpiling used electronic equipment, while South Korea has devised a stockpiling strategy to avoid shortages (Ernst \& Young, 2011). In summary, governments all over the world are acting to deal with and prevent, natural resource shortages and supply instability. Different measures are being taken, and, more often than not, governments are directly inserting themselves in (imperfect) market processes. An increased attention to natural resource scarcity and material efficiency is evident, presenting organizational scholars with a rich context into which to contribute evidence. 


\section{From Blood Diamonds to Fresh Water: Social Impacts of Natural Resources}

It has been argued that persistent natural resource scarcity is associated with increases in material inequality, the intensification of international and national conflicts and institutional shifts toward more closed and authoritarian regimes (Gurr, 1985). For society at large, resource extraction externalities, such as pollution and soil toxification, shortages of essential resources and the possible consequences associated with externalities and shortages, such as unrest, conflict, war, hunger, drought and mass migration, pose grand challenges. These challenges not only affect governments and organizations but also individuals who work in affected environments, face shortages or risk falling victim to war or becoming refugees.

In this light, individual citizens and employees can be gravely affected by scarcity related problems. In a study of 144 countries between 1985 and 2007, Apodaca (2012) found that scarcity indicators such as the cereal yield, the presence of water resources and forest depletion give rise to anti-government demonstrations, strikes and riots, and that the latter are also associated with increases in human rights violations that threaten the physical integrity of the person. Therefore, citizens who live in territories where scarcity is prevalent are not only at risk because of scarcity of fundamental resources like food, water and clean air, but also face a higher likelihood of conflict. While this creates corporate opportunities for frugal innovation - for example, the circular economy, recycling, increasing resource efficiency and dematerialization - finding suitable ways to tackle these issues could be instrumental for governments' and corporations' license to operate.

Regarding water specifically, the UN inter-agency UN-Water (2014) has identified that approximately two out of three people will live in waterstressed areas by 2025. The United Nations Environment Programme (Diop et al., 2008) confirmed that resource shortages and environmental degradation (which often go hand in hand) risk becoming triggers for armed conflicts, especially in the Middle East and Africa. Gleick (2014) tied water shortages to the rise of social unrest in Syria and the ensuing mass migrations that are flooding Europe. Now, Tibet - a mass provider of fresh water to a dozen nations downstream, serving over a third of the global population directly and through feeding rivers like the Indian Ganges - is at the epicentre of the water debates in Asia. Given China's control over Tibet and its refusal to sign the 1997 UN Convention on the Law of the Non-Navigational Uses of International Watercourses, water remains 'the most important global resource that does not have any international agreement' (Pearce, 2012). The treaty finally came into force on 
17 August 2014, but, with only 36 ratifications, it still lacks broad support, especially from key nations.

When civil society is strong and has the backing of local governments, global companies like Coca-Cola will respond. The company was held accountable for creating water shortages and pollution in India, and reacted by setting ambitious water neutrality goals that it claimed it would attain by the end of 2015 (Srivastava, 2015). This is not strictly an issue faced only by developing countries, as Nestlé has come under attack for its water extraction, at record low prices, in California while the entire state suffered from shortages (Bernish, 2015). In August 2015, more than 60 leading Western institutional investors - worth a total of 2.6 trillion USD in assets - sent joint letters to 15 food and beverage companies, calling for increased water risk management and disclosure practices ( $\mathrm{McNally}$, 2015). Water preservation and sustainable management are thus becoming a financial imperative.

Researchers have found that individuals are willing to allocate scarce resources to people in need when resource allocation can be done efficiently, but not when the resource allocators feel that others are responsible for their own predicament (Skitka and Tetlock, 1992). More recently, Fisman et al. (2015) found that, when playing a dictator game, the American elite favours efficiency over equality more than the average American. Hence, only when the cost of resource redistribution is very low are elite citizens willing to come up with a fair and equitable distribution. Such issues of resource access, distribution and power of controlling resources are dominant issues for which management scholars can provide a meaningful thought leadership.

\section{FROM SCARCITY TO SUSTAINABILITY: A CONVERSATION WITH TENG LIT LIAK}

The complement to natural resource scarcity is 'sustainability' - preserving and renewing natural resources extends the time frame for resource use or mitigates its negative impact through regeneration and other processes. In the following section, we highlight extracts from discussions with Teng Lit Liak, who chairs the National Environmental Agency of Singapore, to develop thematic challenges confronting natural resources and sustainability discussions from a practice and policy perspective, including: (a) individual and societal attitudes and behaviours; (b) technology substitution and adoption; (c) agenda shaping, leadership and governance and (d) approaches to sustainability. 


\section{Attitudes and Behaviours}

When we think of protecting wildlife, we focus on lions and whales. Not that they are not important, but we forget the mangroves, the bumblebees, and the insects which are critical to our oceans and food ecosystems. We need our children to learn about ecological balance in the early years. We are like most people in the world - detached from the natural world. Everybody agrees on global warming, but how many of us turn those ideas into action?

Sustainability requires an attitude towards conservation and preservation of the earth's natural resources for the next generations. Yet, these attitudes are not widely shared. Even if individuals do share sustainability principles, their behaviour is often guided by the constraints of the present. Education can help to imbue young minds with a sense of ecological balance, to counter the detachment from the natural world many of us subconsciously experience. These attitudes and behaviours towards sustainability practices become important predictors of investing in technologies or opportunities for the future. Sonenshein and colleagues (2014) studied the importance of self-evaluations and found that factors such as self-doubt play a crucial role in whether individuals waver in their support for environmental action.

Research on boards of directors and top management teams could investigate whether specific forms of short-term versus long-term compensation schemes affect companies' strategic directions when it comes to control over natural resources and investing in novel technologies. Cultural aspects likely play an important role, as Asian countries embarking on growth might have differing incentives to those of mature economies of the West and have differing institutional and societal priorities and views of the world (Barkema et al., 2015). Are forward-thinking boards and managers less likely to engage in strictly symbolic actions? Do they implement resource mechanisms that do not burden future generations; for instance, avoiding landfilling their products at the end of life and enacting recycle and reuse strategies? Such questions tap into the complex cultural, attitudinal and behavioural influences on natural resource scarcity and sustainability.

\section{Technology Substitution and Adoption}

Singapore is one of the few first-world cities located in hot, humid weather. Yet, what is the difference between our skyline and London? It's identical. My point is this: all our buildings in Singapore can be covered with plants, on the roofs and balconies. If a super-clean hospital can have a farm on the roof, you can have compact farming on every HDB [housing development board] flat. One way is to spec the green replacement ratio from 1-to-1 to 1-to-3 or 1-to-5. We need to rethink how we design our buildings and how we use technology. Our 
farming can no longer use millions of acres, but we need to think of technology and compact farming. In the future, you will get your food straight from highdensity compact farms located in high-rise green buildings. We need a whole new way to look at technology and its role in sustaining natural resources.

The technological challenge primarily consists of the risk of solving one problem while worsening another. Desalination of water is highly energy intensive while reverse osmosis could have potentially negative health consequences, due to demineralization, which makes effectively capturing and storing rainwater highly important. Frugal innovations for harvesting rainwater might not be as technologically advanced, but can contribute substantively to sustainability goals. Alternatively, are natural resource constraints going to rejuvenate economic ideas around 'small is beautiful', perhaps facilitated by technologies that allow for more distributed and decentralized ownership (Buterin, 2013; Schumacher, 1973)? It is likely that future farming practices will differ substantively from current practices, perhaps with rooftop farms and vertical gardens penetrating the skyline of cities and villages all over the world. What is the role that entrepreneurs play in sustainability shifts? Can institutional entrepreneurs help change the rules that have become counterproductive to the new objectives? Organizational scholars have opportunities to study shifts in production and consumption, as well as emergence and adoption of new technologies and practices. These questions raise several implications for theories of technology adoption and diffusion when market mechanisms are not the only ones at play.

\section{Agenda Shaping, Leadership and Governance}

The challenges of the future are more grounded than fanciful. You'll always need clean air, you need to eat, you need to keep the aircon on, and the trains running. Yet the big thing will be that we shift from coal generation to sustainable power. Global warming sooner than later is going to catch up with you, whether you deny it exists or not. Where we need leadership is to decide the direction and put all our efforts towards it. You need to look at how leaders and business can take responsibility and shape the agenda. It takes about four calories of energy to create one calorie of food, because of transport, packaging, and manufacturing. We need solutions that cut across countries, businesses, and communities, and this takes leadership and a commitment for better governance globally.

In a recent economics article, Aghion and Roulet (2014) argued that developed nations must become 'smart States' that vertically invest in sectors of strategic interest. This, the authors acknowledged, will involve creative destruction and hence requires a government that is willing to bite the 
hand that feeds it. It requires divesting in sectors in which a country has no advantage, and investing strategically in the big challenges a country faces, which can be scaled across the globe. At the State level, this raises questions about re-education, and thus learning, unlearning, knowledge rigidity and individual and institutionalized inertia. How does an economy transform the skills it has into the skills it needs for the future? Shifts in strategic industries likely will provide avenues for scholars to examine the dynamics of motivation, change and re-skilling workforce issues.

In addition, successfully manoeuvring governmental, civil and nonprofit stakeholders is likely to be especially important in these contexts. China's Three Gorges Dam, the biggest electricity plant in the world, in combination with the South-to-North water project has forced the relocation of more than 1.3 million people, has a detrimental impact on water quality, as algae grow excessively in stationary water, has contributed to the expansion of the Gobi Desert and risks increasing the salinity of the Brahmaputra River in India (Lubin and Schafer, 2010). Given unpredictable externalities and complex resource interactions, firms will need to engage with stakeholders in proactive ways. Models of organizing that include public and private organizations working together with civil society to manage social resilience and welfare will raise new questions of organizational design, coordination, incentives and goal alignment in shaping complex global agendas and implementing coordinated actions across nations and organizations (van der Vegt et al., 2015). For example, public-private partnership models in health care (for example, Roehrich et al., 2014) may well be extended to natural resource sustainability initiatives that involve civil society, organizations and governments.

\section{Approaches to Sustainability: Experimentation, Idealism and Pragmatism}

We need leaders who can think big, think deeply, start small, and act fast.
Thinking big is about breaking through existing boundaries, it is about imagi-
nation. You need to think deeply about problems and require applying rigor
and expertise to ideas, explore and prototype. If we start small and in a sensible
place, it's most likely going to catch on as an experiment. Acting fast requires
us to have ambition, courage, and self-confidence. We need vision and a frame-
work to get bold ideas to practice. What are good ways to lead change? How
can we get business, government, and society to have a bolder vision and to act?

How can governments and organizations stimulate the emergence of ecosystems around new technologies that have the potential to answer some of the 'grand challenges' the world faces regarding environmental sustainability, migration, health and social balance? In these contexts, it is often scarcity that inspires great ideas and actions. Thus, Singapore has 
an advantage in the search for water technologies, because it virtually has no natural water sources of its own. Israel is an early adopter of electrical vehicles because it is keen to reduce its oil dependencies. The Dutch are global experts in the construction of dikes because, without them, one might best visit the Netherlands on a scuba-diving tour. How do slack and problematic searches inspire different practices? Do organizations that hail from countries that face significant natural resource constraints benefit from their difficult access to resources? Is there a corporate equivalent of the resource curse? Scholarship and the evidence that management scholars generate have the potential to influence how organizations can adapt or, better yet, lead the charge to tackle scarcity and shift the emphasis to sustainability. We encourage management and organizational scholars to respond to the grand challenge of the scarcity and sustainability of Earth's natural resources by finding ways to engage business, government and civil society productively, as outlined in this editorial.

The best way to make a living in this world is to find ways of solving problems that everybody has. Every society needs to find its own niche and solve the problems most pertinent to its development. How will it decide? How will it experiment? You need a combination of idealism and pragmatism. Resources can be bought, used, burnt, or thrown away, that's pragmatic, but, then, there's also conservation and how you preserve the world for the next generation. Whether it's recycling batteries or dumping e-waste, there is a business and social opportunity and a cost. At the current cost of oil, does it make sense to recycle plastic? If it is only market economics, likely not. But that also creates an entrepreneurial opportunity for us to find ways to recycle plastic at low cost. I believe that you need to err to the idealistic and push the boundary.

\section{NOTES}

* This chapter is a reprint from an editorial previously published in the Academy of Management Journal, 2015, Vol. 58, No. 6, pp. 1595-613.

1. As at 5 October 2015 .

2. 'Natural resource' OR wind OR oil OR gas OR solar OR steel OR energy OR renewable OR 'natural environment' OR nature OR water OR forest OR diamond OR coal OR 'material' OR input OR throughput OR metal OR land OR agriculture OR food.

3. The UK's Defra (2011), the European Commission (2010, 2011), the US National Research Council (2008) and the US Department of Energy (2011) to name but a few key players. 


\section{REFERENCES}

Aghion, P. and A. Roulet. 2014. Growth and the smart state. Annual Review of Economics, 6: 913-26.

Allwood, J.M., M.F. Ashby, T.G. Gutowski and E. Worrel. 2011. Material efficiency: A white paper. Resources, Conservation and Recycling, 55: 362-81.

Amezcua, A.S., M.G. Grimes, S.W. Bradley and J. Wiklund. 2013. Organizational sponsorship and founding environments: A contingency view on the survival of business-incubated firms, 1994-2007. Academy of Management Journal, 56: $1628-54$.

Apodaca, C. 2012. Human rights violations in an era of scarcity. Paper presented at the Western Political Science Association conference. Retrieved from wpsa. research.pdx.edu/meet/2012/apodaca.pdf. Accessed 1 November 2015.

Aragon-Correa, J.A. 1998. Strategic proactivity and firm approach to the natural environment. Academy of Management Journal, 41: 556-67.

Arthur, J.B. 1994. Effects of human resource systems on manufacturing performance and turnover. Academy of Management Journal, 37: 670-87.

Barkema, H., X.P. Chen, G. George, Y. Luo and A. Tsui. 2015. West meets East: New concepts and theories. Academy of Management Journal, 58: 460-79.

Barney, J.B. 1991. Firm resources and sustained competitive advantage. Journal of Management, 17: 99-120.

Berchicci, L. and A. King. 2007. Postcards from the edge: A review of the business and environment literature. Academy of Management Annals, 1(1): 513-47.

Bernish, C. 2015, 20 August. The privatization of water: Nestle pays only $\$ 524$ to extract 27,000,000 gallons of California drinking water. The AntiMedia. Retrieved from http://theantimedia.org/nestle-pays-only-524-to-exract27000000-gallons-of-california-drinking-water/. Accessed 1 September 2015.

Bhambri, A. and J. Sonnenfeld. 1988. Organization structure and corporate social performance: A field study in two contrasting industries. Academy of Management Journal, 31: 642-62.

Blumberg, M. 1980. Job switching in autonomous work groups: An exploratory study in a Pennsylvania coal mine. Academy of Management Journal, 23: 287-306.

Bode, C., S.M. Wagner, K.J. Petersen and L.M. Ellram. 2011. Understanding responses to supply chain disruptions: Insights from information processing and resource dependence perspectives. Academy of Management Journal, 54: 833-56.

Boone, C. and S. Özcan. 2014. Why do cooperatives emerge in a world dominated by corporations? The diffusion of cooperatives in the U.S. bio-ethanol industry, 1978-2013. Academy of Management Journal, 57: 990-1012.

Brown, G.M. and B.C. Field. 1978. Implications of alternative measures of natural resource scarcity. Journal of Political Economy, 86: 229-43.

Buijs, B. and H. Sievers. 2012. Resource security risks in perspective - Complexity and nuance. POLINARES working paper no. 33, March 2012. Paper presented as Annex I of the Deliverable D02.1 ('Potential sources of competition, tension and conflict and potential solutions') POLINARES project, University of Dundee, Dundee, Scotland.

Buller, P.F. and C.H. Bell, Jr. 1986. Effects of team building and goal setting on productivity: A field experiment. Academy of Management Journal, 29: 305-28.

Buterin, V. 2013, 20 September. Bootstrapping a decentralized autonomous corporation: Part 1. Bitcoin Magazine. Retrieved from https://bitcoinmagazine. 
com/articles/bootstrapping-a-decentralized-autonomouscorporation-parti-1379644274. Accessed 1 November 2015.

Call, M.L., A.J. Nyberg, R.E. Ployhart and J. Weekley. 2015. The dynamic nature of collective turnover and unit performance: The impact of time, quality, and replacements. Academy of Management Journal, 58: 1208-32.

Carrington, D. 2015, 5 February. World's biggest sovereign wealth fund dumps dozens of coal companies. The Guardian. Retrieved from http://www.theguard ian.com/environment/2015/feb/05/worlds-biggest-sovereign-wealth-funddumpsdozens-of-coal-companies. Accessed 1 November 2015.

Chatterjee, S. 1990. Excess resources, utilization costs, and mode of entry. Academy of Management Journal, 33: 780-800.

Cheng, B., I. Ioannou and G. Serafeim. 2014. Corporate social responsibility and access to finance. Strategic Management Journal, 35(1): 1-23.

Chreim, S., B.E. Williams and C.R. Hinings. 2007. Interlevel influences on the reconstruction of professional role identity. Academy of Management Journal, 50: $1515-39$.

Christmann, P. 2000. Effects of 'best practices' of environmental management on cost advantage: The role of complementary assets. Academy of Management Journal, 43: 663-80.

Chua, R.Y.J., P. Ingram and M.W. Morris. 2008. From the head and the heart: Locating cognition- and affect based trust in managers' professional networks. Academy of Management Journal, 51: 436-52.

Collins, C.J. and K.D. Clark. 2003. Strategic human resource practices, top management team social networks, and firm performance: The role of human resource practices in creating organizational competitive advantage. Academy of Management Journal, 46: 740-51.

Cordano, M. and I.H. Frieze. 2000. Pollution reduction preferences of U.S. environmental managers: Applying Ajzen's theory of planned behavior. Academy of Management Journal, 43: 627-41.

Cordery, J.L., W.S. Mueller and L.M. Smith. 1991. Attitudinal and behavioral effects of autonomous group working: A longitudinal field study. Academy of Management Journal, 34: 464-76.

Daft, R.L. 1978. System influence on organizational decision making: The case of resource allocation. Academy of Management Journal, 21: 6-22.

Dean, T.J. and R.L. Brown. 1995. Pollution regulation as a barrier to new firm entry: Initial evidence and implications for future research. Academy of Management Journal, 38: 288-303.

Defra. 2011. Government review of waste policy in England 2011. PB13540. London, England: Defra. Retrieved from https://www.gov.uk/government/uploads/system/ uploads/attachment_data/file/69401/pb13540-waste-policy-review110614.pdf. Accessed 1 November 2015.

Defra. 2012. Resource security action plan: Making the most of valuable materials. PB13719. London, England: Defra. Retrieved from https://www.gov.uk/govern ment/uploads/system/uploads/attachment_data/file/69511/pb13719-resource-se curity-action-plan.pdf. Accessed 1 November 2015.

Delmas, M.A. and O.R. Young. 2009. Governance for the Environment, New Perspectives. New York: Cambridge University Press.

Delmas, M.A., M.V. Russo and M.J. Montes-Sancho. 2007. Deregulation and environmental differentiation in the electric utility industry. Strategic Management Journal, 28(2): 189-209. 
Diestre, L. and N. Rajagopalan. 2011. An environmental perspective on diversification: The effects of chemical relatedness and regulatory sanctions. Academy of Management Journal, 54: 97-115.

Diestre, L. and N. Rajagopalan. 2014. Toward an input-based perspective on categorization: Investor reactions to chemical accidents. Academy of Management Journal, 57: 1130-53.

Diop, S., P. M'mayi and D. Lisbjerg. 2008. Vital water graphics: An overview of the state of the world's fresh and marine waters (2nd ed.). Nairobi, Kenya: United Nations Environment Programme. Retrieved from http://www.unep.org/dewa/ vitalwater/. Accessed 1 November 2015.

Dreher, G.F. 1982. The role of performance in the turnover process. Academy of Management Journal, 25: 137-47.

Dyer, J.S. 1970. The use of PPBS in a public system of higher education: Is it costeffective? Academy of Management Journal, 13: 285-99.

Dyer, J.H. and H. Singh. 1998. The relational view: Cooperative strategy and sources of interorganizational competitive advantage. Academy of Management Review, 23: 660-79.

EEF. 2012. Executive survey 2012: Manufacturers' views on the economy and their own prospects in 2012. London, England: EEF - The Manufacturers' Organization.

Egri, C.P. and S. Herman. 2000. Leadership in the North American environmental sector: Values, leadership styles, and contexts of environmental leaders and their organizations. Academy of Management Journal, 43: 571-604.

Ernst \& Young. 2011. Technology minerals: The rare earths race is on! EYG no. ER0023. London, England: Ernst \& Young's Global Mining and Metals Center.

Ernst \& Young. 2012. Preparing for water scarcity: Raising business awareness on water issues. EYG no. DX0118. London, England: Ernst \& Young. Retrieved from http://www.ey.com/Publication/vwLUAssets/Preparing_for_water_scarcity_-_Ra ising_business_awareness_on_water_issues/\$FILE/EY_Preparing_for_water_sca rcity.pdf. Accessed 1 November 2015.

Ernst \& Young. 2013. Six growing trends in corporate sustainability. London, England: EYGM Limited. Retrieved from http://www.ey.com/Publication/vwLU Assets/Six_growing_trends_in_corporate_sustainability_2013/\$FILE/Six_growi ng_trends_in_corporate_sustainability_2013.pdf. Accessed 1 November 2015.

Ertug, G. and F. Castellucci. 2013. Getting what you need: How reputation and status affect team performance, hiring, and salaries in the NBA. Academy of Management Journal, 56: 407-31.

European Commission. 2010. Critical raw materials for the EU: Report of the ad-hoc working group on defining critical raw materials. Brussels, Belgium: European Commission. Retrieved from https://ec.europa.eu/growth/tools-databases/eip-raw-materials/en/system/files/ged/79\%20report-b_en.pdf. Accessed 1 November 2015.

European Commission. 2011. Roadmap to a resource efficient Europe. COM (2011) 571. Brussels, Belgium: European Commission. Retrieved from http:// eur-lex.europa.eu/legal-content/EN/TXT/PDF/?uri5CELEX:52011DC0571\&fr om5EN. Accessed 1 November 2015.

Federal Ministry of Economics. 2010. The German Government's raw materials strategy: Safeguarding a sustainable supply of non-energy mineral resources for Germany. Berlin, Germany: Bundesministerium für Wirtschaft und Technologie (Federal Ministry of Economics and Technology). Retrieved from http://www. 
bmwi.de/English/Redaktion/Pdf/raw-materials-strategy,property $=$ pdf, bereich $=$ bmwi2012,sprache $=$ en,rwb = true.pdf. Accessed 1 November 2015.

Fernández, E., J.M. Montes and C.J. Vazquez. 2000. Typology and strategic analysis of intangible resources: A resource-based approach. Technovation, 20: 81-92.

Fisman, R., P. Jakiela, S. Kariv and D. Markovits. 2015. The distributional preferences of an elite. Science, 349: 1300-1307.

Flannery, B.L. and D.R. May. 2000. Environmental ethical decision making in the U.S. metal-finishing industry. Academy of Management Journal, 43: 642-62.

Gardner, H.K., B.R. Staats and F. Gino. 2012. Dynamically integrating knowledge in teams: Transforming resources into performance. Academy of Management Journal, 55: 998-1022.

Geletkanycz, M.A. and B.K. Boyd. 2011. CEO outside directorships and firm performance: A reconciliation of agency and embeddedness views. Academy of Management Journal, 54: 335-52.

George, G. 2005. Slack resources and the performance of privately held firms. Academy of Management Journal, 48: 661-76.

George, J.M. and Z. Jing. 2007. Dual tuning in a supportive context: Joint contributions of positive mood, negative mood, and supervisory behaviors to employee creativity. Academy of Management Journal, 50: 605-22.

Gilbert, C. 2005. Unbundling the structure of inertia: Resource versus routine rigidity. Academy of Management Journal, 48: 741-63.

Gleick, P.H. 2014. Water, drought, climate change, and conflict in Syria. Weather, Climate, and Society, 6: 331-40.

Gong, Y. 2003. Subsidiary staffing in multinational enterprises: Agency, resources, and performance. Academy of Management Journal, 46: 728-39.

Grant, R.M. 1999. The resource-based theory of competitive advantage: Implications for strategy formulation. In M.H. Zack (ed.), Knowledge and Strategy, vol. 33: 3-23. Boston, MA: Butterworth Heinemann.

Grantham, J. 2012. Attitudes in America to investing, resource limitations and global warming. Paper presented at the Imperial College Lectures, London.

Gurr, T.T. 1985. On the political consequences of scarcity and economic decline. International Studies Quarterly, 29: 51-75.

Hand, H.H. and J.W. Slocum, Jr. 1970. Human relations training for middle management: A field experiment. Academy of Management Journal, 13: 403-10.

Hardy, C. and S. Maguire. 2010. Discourse, field-configuring events, and change in organizations and institutional fields: Narratives of DDT and the Stockholm Convention. Academy of Management Journal, 53: 1365-92.

Hayes-Labruto, L., S.J.D. Schillebeeckx, M. Workman and N. Shah. 2013. Contrasting perspectives on China's rare earth policies: Reframing the debate through a stakeholder lens. Energy Policy, 63: 55-68.

He, J. and H.C. Wang. 2009. Innovative knowledge assets and economic performance: The asymmetric roles of incentives and monitoring. Academy of Management Journal, 52: 919-38.

Heffernan, T. 2015. The U.S.'s only rare-earth mine files for bankruptcy. High Country News. Retrieved from http://www.hcn.org/articles/the-u-s-s-only-rareearth-mine-files-bankruptcy. Accessed 1 November 2015.

Henriques, I. and P. Sadorsky. 1999. The relationship between environmental commitment and managerial perceptions of stakeholder importance. Academy of Management Journal, 42: 87-99.

Herlocker, C.E., S.T. Allison, J.D. Foubert and J.K. Beggan. 1997. Intended and 
unintended overconsumption of physical, spatial, and temporal resources. Journal of Personality and Social Psychology, 73: 992-1104.

Hiatt, S.R. and P. Sangchan. 2013. Lords of the harvest: Third-party influence and regulatory approval of genetically modified organisms. Academy of Management Journal, 56: 923-44.

Hitt, M.A., L. Bierman, K. Uhlenbruck and K. Shimizu. 2006. The importance of resources in the internationalization of professional service firms: The good, the bad, and the ugly. Academy of Management Journal, 49: 1137-57.

Hoffman, A.J. 1999. Institutional evolution and change: Environmentalism and the U.S. chemical industry. Academy of Management Journal, 42: 351-71.

Homan, A.C., J.R. Hollenbeck, S.E. Humphrey, D. Van Knippenberg, D.R. Ilgen and G.A. Van Kleef. 2008. Facing differences with an open mind: Openness to experience, salience of intragroup differences, and performance of diverse work groups. Academy of Management Journal, 51: 1204-22.

Hook, L., J. Chaffin and A. Beattie. 2012, 13 March. Fight against China on rare earths. Financial Times. Retrieved from http://www.ft.com/cms/s/0/4c3da2946cc2-11e1-bd0c-00144feab49a.html. Accessed 1 November 2015.

Hotelling, H. 1931. The economics of exhaustible resources. Journal of Political Economy, 39: 137-75.

Howard-Grenville, J., S.J. Buckle, B.J. Hoskins and G. George. 2014. Climate change and management. Academy of Management Journal, 57: 615-23.

Humphries, M. 2013. Rare earth elements: The global supply chain. CRS report for Congress, R41347. Washington, DC: Congressional Research Service. Retrieved from http://fas.org/sgp/crs/natsec/R41347.pdf. Accessed 1 November 2015.

Ioannou, I. and G. Serafeim. 2012. What drives corporate social performance? The role of nation-level institutions. Journal of International Business Studies, 43(9): 834-64.

Jensen, M. and A. Roy. 2008. Staging exchange partner choices: When do status and reputation matter? Academy of Management Journal, 51: 495-516.

Joshi, A., B. Neely, C. Emrich, D. Griffiths and G. George. 2015. Gender research in AMJ: An overview of five decades of research and call to action. Academy of Management Journal, 58: 1459-475.

Kassinis, G. and N. Vafeas. 2006. Stakeholder pressures and environmental performance. Academy of Management Journal, 49: 145-59.

King, A. 2015. Why it pays to become a rule maker. MIT Sloan Management Review, 56(2): 11.

Lamin, A. 2013. Business groups as information resource: An investigation of business group affiliation in the Indian software services industry. Academy of Management Journal, 56: 1487-509.

Lee, B.H. 2009. The infrastructure of collective action and policy content diffusion in the organic food industry. Academy of Management Journal, 52: 1247-69.

Lubin, G. and I. Schafer. 2010. 17 earthshaking facts about the Three Gorges Dam and China's next even bigger water project. Business Insider. Retrieved from http://www.businessinsider.com/three-gorges-damsouth-to-north-waterdiverson-project-china-2010-7?IR5T. Accessed 1 November 2015.

Madhavan, R., D.R. Gnyawali and H. Jinyu. 2004. Two's company, three's a crowd? Triads in cooperative-competitive networks. Academy of Management Journal, 47: 918-27.

Madsen, P.M. 2009. Does corporate investment drive a 'race to the bottom' in 
environmental protection? A reexamination of the effect of environmental regulation on investment. Academy of Management Journal, 52: 1297-318.

Maguire, S. and C. Hardy. 2009. Discourse and deinstitutionalization: The decline of DDT. Academy of Management Journal, 52: 148-78.

Malthus, T.R. 2005. An Essay on the Principle of Population. New York: Cosimo. (Original work published 1798. Reproduction of J.M. Dent, London, and E.P. Dutton, New York, 1914.)

Marcus, A.A. 1988. Implementing externally induced innovations: A comparison of rule-bound and autonomous approaches. Academy of Management Journal, 31: 235-56.

Martin, R. 2011, 18 November. Molycorp's \$1 billion rare earth gamble. Fortune. Retrieved from http://fortune.com/2011/11/18/molycorps-1-billion-rare-earthgamble/. Accessed 1 November 2015.

Mayer, K.J. and R.M. Salomon. 2006. Capabilities, contractual hazards, and governance: Integrating resource-based and transaction cost perspectives. Academy of Management Journal, 49: 942-59.

McClean, E.J., E.R. Burris and J.R. Detert. 2013. When does voice lead to exit? It depends on leadership. Academy of Management Journal, 56: 525-48.

McDonough, W. and M. Braungart. 2002. Cradle to cradle: Remaking the way we make things. New York: North Point Press.

McFadyen, M.A. and A.A. Cannella. 2004. Social capital and knowledge creation: Diminishing returns of the number and strength of exchange relationships. Academy of Management Journal, 47: 735-46.

McNally, B.W. 2015. Coca-Cola on track to being water neutral by end of 2015. Supply Chain. Retrieved from http://www.sustainablebrands.com/news_and_ views/supply_chain/brynn_mcnally/coca-cola_says_its_track_being_water_neut ral_end_2015. Accessed 1 November 2015.

Meadows, D.H., J. Randers and D. Meadows. 2004. Limits to growth: The 30-year update. White River Junction, VT: Chelsea Green Publishing.

Meadows, D.H., D.L. Meadows, J. Randers and W.W. Behrens. 1972. The limits to growth: A report for the Club of Rome's project on the predicament of mankind. New York: Potomac Associates.

Mitsuhashi, H. and H.R. Greve. 2009. A matching theory of alliance formation and organizational success: Complementarity and compatibility. Academy of Management Journal, 52: 975-95.

Miyazaki, T. 2012. Japan [and] India reach rare earth deal. The Jakarta Post. Retrieved from http://www.thejakartapost.com/news/2012/05/02/japan-indiareach-rare-earth-deal.html. Accessed 1 November 2015.

Osborn, R.N. and D.H. Jackson. 1988. Leaders, riverboat gamblers, or purposeful unintended consequences in the management of complex, dangerous technologies. Academy of Management Journal, 31: 924-47.

Parikh, P., S. Chaturvedi and G. George. 2012. The effects of energy provision on individual aspiration in slum communities. Energy Policy, 50: 477-85.

Parikh, P., K. Fu, H. Parikh, A. McRobie and G. George. 2015. Infrastructure provision, gender, and poverty in Indian slums. World Development, 66: 468-86.

Pearce, F. 2012. A global treaty on rivers: Key to true water security. Yale Environment 360. Retrieved from https://e360.yale.edu/feature/a_global_treaty_ on_rivers_key_to_true_water_security/2594/. Accessed 1 November 2015.

Pennings, J.M. 1982. The urban quality of life and entrepreneurship. Academy of Management Journal, 25: 63-79. 
Polidoro, F., Jr., 2013. The competitive implications of certifications: The effects of scientific and regulatory certifications on entries into new technical fields. Academy of Management Journal, 56: 597-627.

Polidoro, F., Jr and P.K. Toh. 2011. Letting rivals come close or warding them off? The effects of substitution threat on imitation deterrence. Academy of Management Journal, 54: 369-92.

Powell, E.E. and T. Baker. 2014. It's what you make of it: Founder identity and enacting strategic responses to adversity. Academy of Management Journal, 57: 1406-33.

PwC. 2011. The true value of water: Best practices for managing water risks and opportunities. A PwC Global Best Practices focus paper. Retrieved from http:// www.pwc.com/gx/en/sustainability/publications/assets/pwc-thevalue-of-water.pdf. Accessed 1 November 2015.

Ramus, C.A. and U. Steger. 2000. The roles of supervisory support behaviors and environmental policy in employee 'ecointiatives' at leading-edge European companies. Academy of Management Journal, 43: 605-26.

Ricardo, D. 2014. On the principles of political economy and taxation. Cambridge: Cambridge University Press. (Original work published 1817 by John Murray, London, England).

Rockström, J., W. Steffen, K. Noone, Å. Persson, F.S. Chapin, E. Lambin, T.M. Lenton, M. Scheffner, C. Folke, H.J. Schellnhuber, B. Nykvist, C.A. de Wit, T. Hughes, S. van der Leeuw, H. Rodhe, S. Sörlin, P.K. Snyder, R. Costanza, U. Svedin, M. Falkenmark, L. Karlberg, R.W. Corell, V.J. Fabry, J. Hansen, B. Walker, D. Liverman, P. Crutzen and J.A. Foley. 2009. Planetary boundaries: Exploring the safe operating space for humanity. Ecology and Society, 14: 32. Retrieved from http://www.ecologyandsociety.org/vol14/iss2/art32/. Accessed 1 November 2015.

Rodell, J.B. 2013. Finding meaning through volunteering: Why do employees volunteer and what does it mean for their jobs? Academy of Management Journal, 56: 1274-94.

Roehrich, J., M. Lewis and G. George. 2014. Are public-private partnerships a healthy option? A systematic review. Social Science and Medicine, 113: 110-19.

Rojas, F. 2010. Power through institutional work: Acquiring academic authority in the 1968 third world strike. Academy of Management Journal, 53: 1263-80.

Russo, M.V. 2003. The emergence of sustainable industries: Building on natural capital. Strategic Management Journal, 24(4): 317-31.

Rulli, M.C. and P. D'Odorico. 2014. Food appropriation through large-scale land acquisitions. Environmental Research Letters, 9: 1-8.

Schillebeeckx, S.J., P. Parikh, R. Bansal and G. George. 2012. An integrated framework for rural electrification: Adopting a user-centric approach to business model development. Energy Policy, 48: 687-97.

Schoolderman, H. and R. Mathlener. 2011. Minerals and metals scarcity: The ticking timebomb. A PwC survey. Retrieved from http://www.gilcommunity.com/ files/4113/6318/4685/impact-of-minerals-metals-scarcity-onbusiness.pdf. Accessed 1 November 2015.

Schumacher, E.F. 1973. Small is beautiful: A study of economics as if people mattered. London, England: Blond and Briggs.

Schüssler, E., C.-C. Ruling, and B.B.F. Wittneben. 2014. On melting summits: The limitations of field-configuring events as catalysts of change in transnational climate policy. Academy of Management Journal, 57: 140-71. 
Sharma, S. 2000. Managerial interpretations and organizational context as predictors of corporate choice of environmental strategy. Academy of Management Journal, 43: 681-97.

Shaw, J.D., B.R. Dineen, R. Fang and R.F. Vellella. 2009. Employee-organization exchange relationships, HRM practices, and quit rates of good and poor performers. Academy of Management Journal, 52: 1016-33.

Sirmon, D., S. Gove and M.A. Hitt. 2008. Resource management in dyadic competitive rivalry: The effects of resource bundling and deployment. Academy of Management Journal, 51: 919-35.

Skitka, L.J. and P.E. Tetlock. 1992. Allocating scarce resources: A contingency model of distributive justice. Journal of Experimental Social Psychology, 28: 491-522.

Smaller, C. and H. Mann. 2009. A thirst for distant lands: Foreign investment in agricultural land and water. Winnipeg, Manitoba, Canada: International Institute for Sustainable Development. Retrieved from http://www.iisd.org/ pdf/2009/thirst_for_distant_lands.pdf. Accessed 1 November 2015.

Sonenshein, S. 2014. How organizations foster the creative use of resources. Academy of Management Journal, 57(3): 814 48.

Sonenshein, S., K. DeCelles and J. Dutton. 2014. It's not easy being green: The role of self-evaluations in explaining support of environmental issues. Academy of Management Journal, 57: 7-37.

Srivastava, A. 2015, 29 August. The privatization of water in India: How CocaCola destroys the aquifer. The Centre for Research on Globalization (originally published in The Ecologist, 25 August 2015). Retrieved from http://www.global research.ca/the-privatization-of-waterin-india-how-cocacola-destroys-the-aquif er/5472625. Accessed 1 September 2015.

Srivastava, M.K. and D.R. Gnyawali. 2011. When do relational resources matter? Leveraging portfolio technological resources for breakthrough innovation. Academy of Management Journal, 54: 797-810.

Tenbrunsel, A.E., K.A. Wade-Benzoni, D.M. Messick and M.H. Bazerman. 2000. Understanding the influence of environmental standards on judgments and choices. Academy of Management Journal, 43: 854-66.

Tober, J.A. 1974. The allocation of wildlife resources in the United States 18501900. Unpublished PhD Dissertation, Yale University, Yale.

Tsai, W. 2001. Knowledge transfer in intraorganizational networks: Effects of network position and absorptive capacity on business unit innovation and performance. Academy of Management Journal, 44: 996-1004.

Tsai, W. and S. Ghoshal. 1998. Social capital and value creation: The role of intrafirm networks. Academy of Management Journal, 41: 464-76.

United Nations. 2012. The millennium development goals report 2012. Geneva, Switzerland: United Nations. Retrieved from http://www.un.org/millenni umgoals/pdf/MDG\%20Report\%202012.pdf. Accessed 1 November 2015.

UN-Water. 2014. A post-2015 global goal for water: Synthesis of key findings and recommendations from UN-Water. Geneva, Switzerland: UN-Water. Retrieved from http://www.un.org/waterforlifedecade/pdf/27_01_2014_un-water_paper_ on_a_post2015_global_goal_for_water.pdf. Accessed 1 November 2015.

Upson, J.W., D.J. Ketchen, Jr., B.L. Connelly and A.L. Ranft. 2012. Competitor analysis and foothold moves. Academy of Management Journal, 55: 93-110.

US Department of Energy. 2011. Critical materials strategy. Washington, DC: US Department of Energy. Retrieved from http://energy.gov/sites/prod/files/ DOE_CMS2011_FINAL_Full.pdf. Accessed 1 November 2015. 
US National Research Council. 2008. Managing materials for a twenty-first century military. Washington, DC: National Academies Press.

van der Vegt, G.S. and J.S. Bunderson. 2005. Learning and performance in multidisciplinary teams: The importance of collective team identification. Academy of Management Journal, 48: 532-47.

van der Vegt, G.S., P. Essens, M. Wahlström and G. George. 2015. Managing risk and resilience. Academy of Management Journal, 58: 971-80.

Vateva, A. 2012. China's rare-earth elements policy and its implications for Germany, Japan and the USA. UfU-Paper 1/12. Berlin, Germany: Unabhangiges Institut fur Umweltfragen. Retrieved from http://www.ufu.de/media/content/files/ Fachgebiete/Ressourcenschutz/Publikationen/Vateva_China's\%20Policy\%20on \%20REE.pdf. Accessed 1 November 2015.

Wang, H. and C. Qian. 2011. Corporate philanthropy and corporate financial performance: The roles of stakeholder response and political access. Academy of Management Journal, 54: 1159-81.

Whiteman, G. and W.H. Cooper. 2000. Ecological embeddedness. Academy of Management Journal, 43: 1265-82.

Williamson, I.O. and D.M. Cable. 2003. Organizational hiring patterns, interfirm network ties, and interorganizational imitation. Academy of Management Journal, 46: 349-58.

Workman, M., C. Dean, S.J.D. Schillebeeckx and N. Shah. 2016. Modern resource scarcity: Sinks, complexity, and managing risks. London, England: Grantham Institute - Climate Change and the Environment, Imperial College London.

World Economic Forum. 2008. Global risks 2008, A global risk network report: 1-54. Geneva: World Economic Forum.

Zilber, T.B. 2002. Institutionalization as an interplay between actions, meanings, and actors: The case of a rape crisis center in Israel. Academy of Management Journal, 45: 234-54. 